\title{
Intra-Executive Policy Laundering: A New Look at an Old Problem
}

\author{
Alvin Y.H. Cheung†
}

I. The Traditional Account of Policy Laundering ........253

A. Policy Laundering in the Copyright Sphere.......253

B. Policy Laundering in Other Fields ......................257

C. The Theory Behind Traditional Accounts of Policy

Laundering ........................................................258

II. Intra-Executive Policy Laundering............................ 261

A. The Theory Behind Intra-Executive Policy

Laundering ....................................................2261

B. A Hypothetical Example....................................264

III. Intra-Executive Policy Laundering in Action............ 265

A. When Would Executive Entities Policy Launder? .........................................................2265

B. Example 1-the Basel Accords .........................266

C. Example 2-the European Union and Copyright

Reform ............................................................2268

D. A Counter-Example: When Will an Executive

Actor Act Alone?..............................................2271

IV. Descriptive and Normative Conclusions .................. 272

A. Descriptive Conclusions..................................2272

B. Normative Conclusions .....................................2273

C. Beyond the Language of "Laundering” ...............274

National democratic governance is under siege. In numerous nation-states, the executive branch has used international fora to advance domestically unpopular policies and repatriate such standards under the guise of complying with multilateral

† Of the Hong Kong Bar, Barrister (non-practicing); Lawyer, New York Bar. I am indebted to Professors Benedict Kingsbury and Gráinne de Búrca (both of the NYU School of Law) for their comments on earlier versions of this article, and to Daniel Hemel (University of Chicago Law School) and Alyssa S. King (Yale Law School PhD Candidate) for the discussions that led to this article. All errors remain solely my own. 
obligations. ${ }^{1}$ "Policy laundering," as the practice has been called, has most recently come to the fore in the field of intellectual property, where the interaction between international trade law and intellectual property standards has come under increasing scrutiny. ${ }^{2}$ Multinational corporations in industries reliant on robust intellectual property protection have driven a process of expansionism through the inclusion of intellectual property provisions in trade agreements. ${ }^{3}$ The consequences of this corporate involvement in trade negotiations include the imposition of substantive intellectual property provisions that favor corporate interests, ${ }^{4}$ and the disturbance of the traditional balance between the interests of rights holders and the public interest in access to knowledge. ${ }^{5}$

As a result, opposition to intellectual property provisions in international trade agreements is based as much on procedure as on substance. ${ }^{6}$ Opponents of the Anti-Counterfeiting Trade Agreement (“ACTA") have focused not only on its substantive content, which disregards the need for flexibility and exceptions to intellectual property rights, ${ }^{7}$ but also on the process by which these substantive rules were negotiated. ${ }^{8}$ Similar complaints have dogged the more recent Trans-Pacific Partnership (“TPP”) trade

1 See, e.g., David Kravets, Copyright Treaty Is Policy Laundering at Its Finest, THREAT LEVEL (Nov. 4, 2009), http://www.wired.com//2009/11/policy-laundering/ [http://perma.cc/S7KQ-4KYD] (describing an instance of policy laundering with a copyright treaty).

2 Id.

3 See Susan K. Sell, Private Power, Public Law: The Globalization of InTEllectual Property 96-100 (2003) (describing the formation of the Intellectual Property Committee, formed by executives of US-based multinational corporations, and its role in the negotiations leading to the WTO Trade-Related Aspects of Intellectual Property (“TRIPS”) agreement); Margot E. Kaminski, The Capture of International Intellectual Property Law Through the U.S. Trade Regime, 87 S. CAL. L. REV. 977, 97981 (2014) (describing the institutional capture of the United States Trade Representative by private interests).

4 Kaminski, supra note 3, at 979-84.

5 See Peter K. Yu, Six Secret (and Now Open) Fears of ACTA, 64 SMU L. REv. 975, 1036-37 (2011).

6 See Eddan Katz \& Gwen Hinze, The Impact of the Anti-Counterfeiting Trade Agreement on the Knowledge Economy: The Accountability of the Office of the U.S. Trade Representative for the Creation of IP Enforcement Norms Through Executive Trade Agreements, 35 Yale J. InT'L L. OnLine 24, 24-25 (2009).

7 See id.

8 See id. 
agreement-which was finalized on October 5, 2015. ${ }^{9}$ The final text of the TPP's intellectual property chapter-and successive leaked texts-have been roundly criticized by experts for their restrictiveness. ${ }^{10}$ But concerns about the secrecy in which the TPP was negotiated have become much more potent-and are shared across the political spectrum. ${ }^{11}$ The secrecy with which agreements such as ACTA and TPP have been negotiated have, as a result, given

9 Jackie Calmes, Trans-Pacific Partnership Trade Deal Is Reached, N.Y. TIMES (Oct. 5, 2015), http://www.nytimes.com/2015/10/06/business/trans-pacific-partnershiptrade-deal-is-reached.html [http://perma.cc/KSQ7-XWBJ]. On October 9, 2015, Wikileaks released what appeared to be the final text of the TPP's intellectual property chapter. TPP Treaty: Intellectual Property Rights Chapter - 5 October 2015, WIKILEAKS (Oct. 9, 2015), https://wikileaks.org/tpp-ip3/ [http://perma.cc/Z8KA-JLEJ]. On November 5, 2015, the Office of the United States Trade Representative released the final text of the TPP in its entirety. TPP Full Text, OfF. U.S. Trade RePresentative, https://ustr.gov/trade-agreements/free-trade-agreements/trans-pacific-partnership/tpp-full -text [https://perma.cc/KJ56-J9XX] (last visited Nov. 8, 2015).

10 See, e.g., Jeremy Malcolm \& Maira Sutton, Release of the Full TPP Text After Five Years of Secrecy Confirms Threats to Users' Rights, ElECTRONIC FrontiER Found. (Nov. 5, 2015), https://www.eff.org/deeplinks/2015/11/release-full-tpp-text-after-fiveyears-secrecy-confirms-threats-users-rights [https://perma.cc/SW69-7KFM] (referring to the officially released TPP text); Michael Geist, Canada Caves on Copyright in TPP: Commits to Longer Term, Urge ISPs to Block Content, Michael GeIST (Oct. 9, 2015), http://www.michaelgeist.ca/2015/10/canada-caves-on-copyright-in-tpp-commits-to-longe r-term-urge-isps-to-block-content/ [http://perma.cc/F3RS-UU29] [hereinafter Canada Caves] (criticizing Canadian negotiators for making damaging compromises with respect to the copyright provisions of the leaked version of the final TPP text); Jeremy Malcolm, The Final Leaked TPP Text Is All That We Feared, EleCtRONIC FronTIER Found. (Oct. 9, 2015), https://www.eff.org/deeplinks/2015/10/final-leaked-tpp-text-all-we-feared [http://perma.cc/82Y2-UT7V] (referring to the overwhelmingly rights-holder-friendly nature of the TPP's intellectual property chapter); Michael Geist, Why the Secrecy on the TPP Talks in Ottawa This Week? Because There Is Something to Hide, MicHAEL GEIST (July 7, 2014), http://www.michaelgeist.ca/2014/07/secrecy-tpp-talks-ottawa-weeksomething-hide/ [http://perma.cc/HG9M-ZKGC] [hereinafter Something to Hide] (suggesting that the secrecy of the proposed agreement is meant to conceal the substance of the proposed agreement, which would change and restrict current Canadian policy).

11 See, e.g., Alec MacGillis, Why Obama's Big Trade Deal Isn't a Sure Thing, SLATE (Feb. 2, 2015), http://www.slate.com/articles/news_and_politics/politics/2015/02/demo crats_working_with_tea_party_against_obama_s_trade_deal_the_president.html [http:// perma.cc/G87B-CF3F] (discussing bi-partisan opposition to the lack of transparency in conducting trade deals via the fast track); David M. Goodman, Progressives and Tea Party Find Common Ground as They Oppose the Trans-Pacific Partnership, NJ.com (Feb. 16, 2015), http://www.nj.com/opinion/index.ssf/2015/02/opinion_progressives_and_tea_ party_find_common_gro.html [http://perma.cc/U3KW-EMSW] (“TPP—the secret trade deal many haven't heard of-is also bringing progressives and the Tea Party out in droves, and the noise they are making has the establishment concerned.”). 
rise to allegations of policy laundering. ${ }^{12}$

Yet the current literature on policy laundering paints an incomplete picture. Traditional accounts of policy laundering presuppose the existence of a monolithic executive branch, whose primary opponents are the legislative branch and civil society. ${ }^{13}$ Such an account is insufficient to explain instances in which various branches of the executive appear to be at odds with each other.

I argue that there exists a distinct sub-species of policy laundering, referred to here as "intra-executive policy laundering." International regulatory coordination is not only a vehicle through which the executive as a whole seeks to advance its agenda vis-avis other branches of government-it is also a means through which one executive agency can advance its own substantive agenda, and expand its own domestic regulatory authority vis-a-vis other executive agencies. Consequently, executive agencies will compete to coordinate with counterpart agencies in other states, exacerbating the incidence of policy laundering by the executive as a whole. Intra-executive policy laundering also creates greater difficulties for the legislature and civil society in detecting and opposing policy laundering, as they face a multitude of opponents rather than a monolithic executive. Despite potential benefits in breaking regulatory deadlock and increasing international coordination, this article argues that the lack of transparency and accountability that accompanies intra-executive policy laundering is more pernicious than that associated with policy laundering by a monolithic executive. Ultimately, however, the language of "policy laundering" is misplaced, insofar as it emphasizes a substantive policy pursued by an executive entity, rather than the expansion of that entity's sphere of autonomy.

Part I reviews the existing literature on policy laundering, as well as previous literature referring to the phenomenon as the "new raison d'état" and "collusive delegation." It contends that the traditional account of "policy laundering" refers to a phenomenon in which the executive has two main objectives: to advance a

12 See Katz \& Hinze, supra note 6, at 33 (describing the ACTA); Something to Hide, supra note 10 (describing the TPP).

13 See Oriol Costa \& Knud Erik Jorgensen, The Influence of International Institutions on the EU: A Framework for Analysis, in THE INFLUENCE OF INTERNATIONAL INSTITUTIONS ON THE EU: WHEN MULTILATERALISM Hits BRUSSELS 1,10 (2012). 
particular substantive agenda and to increase its net autonomy (namely the sum of its external autonomy in the international arena and its internal autonomy vis-a-vis the legislature and civil society). Part II provides a brief theoretical account of intra-executive policy laundering. Part III discusses two examples of policy laundering which cannot be adequately explained by traditional accounts of policy laundering, as well as one counter-example, and explains them with reference to the idea of intra-executive policy laundering. Part IV offers some tentative conclusions.

\section{The Traditional Account of Policy Laundering}

The earliest references to "policy laundering" as a phrase date back to 2003. ${ }^{14}$ Yet the process now called "policy laundering” has been addressed in much earlier academic literature. ${ }^{15}$

However, the phrase "policy laundering” brings one particular aspect to the fore: the attempt to implement substantive policies that would not survive domestic political scrutiny through international fora. The phrase itself conjures up parallels with money laundering: If "money laundering" describes the cycling of illegitimate funds through legal structures in order to enter them into legitimate circulation, policy laundering similarly involves recycling policies that lack political legitimacy through outside intuitions in order to get them into circulation despite their lack of acceptance. ${ }^{16}$ This section will first provide examples of policy laundering, both in copyright and in other fields. It will then outline the theoretical discussion of policy laundering, with reference to the literature on the "new raison d'état" and "collusive delegation."

\section{A. Policy Laundering in the Copyright Sphere}

Governments have long sought to advocate particular policies in international fora. ${ }^{17}$ However, the defining feature of policy

14 See infra Part II.A.

15 See infra Part II.A.

16 Aidan White \& Ben Hayes, Journalism, Civil Liberties AND the WAR ON TERRORISM: A SPECIAL REPORT BY THE INTERNATIONAL FEDERATION OF JOURNALISTS AND STATEWATCH 2, 15 (2005), http://www.statewatch.org/news/2005/may/03ifjstatewatch.htm [http://perma.cc/TES9-SH4S].

17 Gus Hosein, Revisiting Policy Laundering and Modern International Policy Dynamics, in ReseARch HANDBOOK ON GOVERnANCE OF THE INTERNET 260, 265 (Ian Brown ed., 2013). I acknowledge that executives in presidential and semi-presidential systems have democratic legitimacy of their own; however, addressing their competing 
laundering is that the laundering executive entity promotes a policy abroad that does not (or does not yet) have domestic consensus or approval. ${ }^{18}$ The laundering entity then seeks to convince the domestic legislature to approve the policy, in order to comply with "international obligations." 19 The domestic legislation advocated by the laundering entity may_or may not—be required by the international instruments in question. ${ }^{20}$

The anti-circumvention provisions of the Digital Millennium Copyright Act ("DMCA") in the United States are a notable early instance of policy laundering in the copyright realm. Anticircumvention refers to legal restrictions on the ability to circumvent digital rights management ("DRM") technologies. DRM systems, such as the Content Scrambling System ("CSS”) used for DVDs, typically seek to prevent the unauthorized copying of digital content. ${ }^{21}$ In principle, such systems could impose other limits on a user's ability to use digital content, such as limits on how long a user can pause a video. ${ }^{22}$ However, the nature of DRMwhich requires the encryption of content to prevent users from accessing it through "unauthorized means," while simultaneously providing users with limited access-renders it inherently vulnerable to circumvention. ${ }^{23}$ Anti-circumvention provisions impose legal restrictions on the ability to make, sell, or use methods of DRM circumvention. ${ }^{24}$

Shortly after President Clinton assumed office, the White House established an "Information Infrastructure Task Force" to formulate the administration's Internet policy. ${ }^{25}$ The task force included a Working Group on Intellectual Property, chaired by Patent Commissioner Bruce Lehman. ${ }^{26}$ Prior to his appointment as Patent

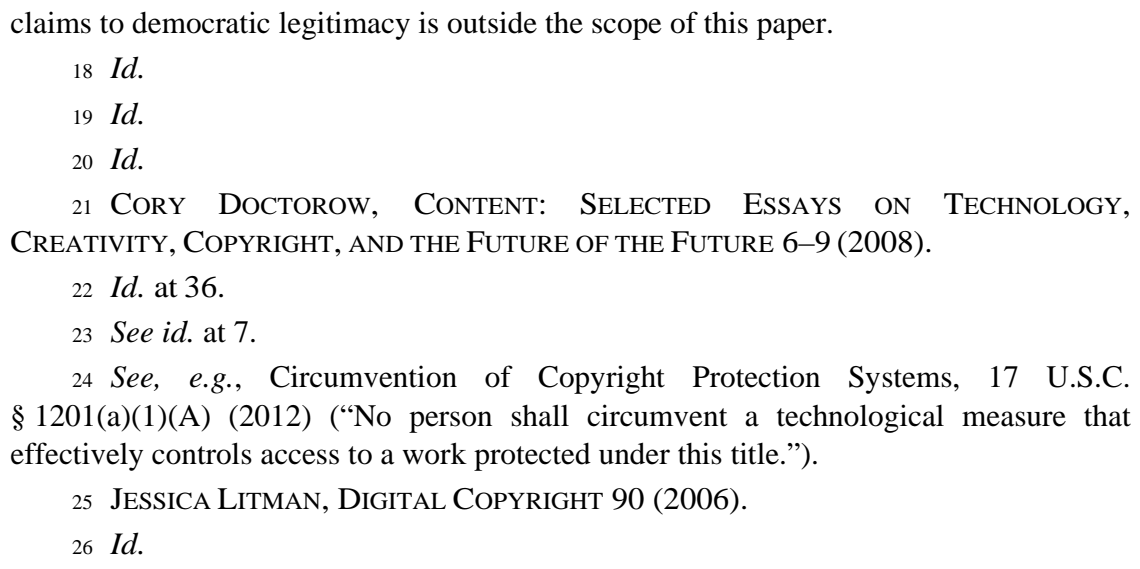


Commissioner, Lehman represented the computer software industry on copyright issues; the Lehman Working Group had extensive communications with private-sector copyright lobbyists. ${ }^{27}$ As a result, the Working Group sought to secure extensive control over digital content for rights holders, ${ }^{28}$ including anti-circumvention provisions. ${ }^{29}$ Faced with intense resistance in Congress, ${ }^{30}$ Lehman lobbied the Office of the United States Trade Representative ("USTR") to propose anti-circumvention at the U.N. World Intellectual Property Organization ("WIPO”). ${ }^{31}$ Lehman's lobbying efforts directly contributed to the inclusion of anti-circumvention provisions in the WIPO Copyright Treaty of 1996 ("WCT"), which formed the basis for the corresponding DMCA provisions. ${ }^{32}$ Speaking about the DMCA in March, 2013, Lehman was accused of using the WIPO treaty process to avoid Congressional opposition to DRM, to which he responded, "I would say that they're right." 33

As alluded to in the introduction, ACTA is a more recent example of policy laundering at work. Negotiated in tight secrecy, the first formal draft of ACTA was published on April 21, 2010 and the final draft in December 2010.34 Even before the formal drafts were released, commentators began to express concerns regarding leaked negotiation texts. ${ }^{35}$ The final text included provisions that expanded the scope of criminal copyright violations, ${ }^{36}$ dictated more stringent border measures, ${ }^{37}$ and encouraged parties to implement

27 Id.

28 See id. at 90-91.

29 See id. at 92-93.

30 See Bill D. Herman \& Oscar H. Gandy, Jr., Catch 1201: A Legislative History and Content Analysis of the DMCA Exemption Proceedings, 24 CARDOZO ARTS \& ENT. L.J. 121, 130-31 (2006).

31 Parker Higgins \& Maira Sutton, How the U.S. Trade Rep Ratchets Up Worldwide Copyright Laws That Could Keep Your Devices Locked Forever, ELECTRONIC FRONTIER Found. (Mar. 26, 2013), https://www.eff.org/deeplinks/2013/03/ustr-secret-copyrightagreements-worldwide [http://perma.cc/EQ6P-CEUS].

32 See Herman \& Gandy, supra note 30.

33 Higgins \& Sutton, supra note 31. (2012).

34 See Kenneth L. Port, A Case Against ACTA, 33 Cardozo L. Rev. 1131, 1156

35 Yu, supra note 5, at 1017.

36 See Anti-Counterfeiting Trade Agreement arts. 23-26, opened for signature May 1, 2011, 50 I.L.M. 243.

37 See id. arts. 13-22. 
"graduated response" schemes for online service providers (entailing the extra-judicial termination of accounts of subscribers alleged to have engaged in repeat copyright infringement). ${ }^{38}$ It also created an unelected ACTA Committee to oversee enforcement. ${ }^{39}$ Many of ACTA's substantive provisions have been rejected by domestic political processes in the United States and elsewhere. ${ }^{40}$ The secretive nature of the process by which ACTA was negotiated, coupled with its IP-maximalist substantive provisions, have given rise to allegations of policy laundering. ${ }^{41}$

The TPP is a still more recent example of policy laundering. Successive texts of the TPP's intellectual property chapter revealed provisions that overwhelmingly favor the interests of rights-holders, at the expense of users, consumers, and countervailing public policy interests. $^{42}$ Commentators such as Canadian professor Michael Geist and the Electronic Frontier Foundation, an NGO, have linked the substantive imbalance of these provisions with the lack of transparency surrounding TPP negotiations. ${ }^{43}$ Flynn and others,

38 See id. pmbl., art. 27.

39 Id. art. 36. On the above provisions generally, see Margot E. Kaminski, An Overview and the Evolution of the Anti-Counterfeiting Trade Agreement (ACTA), 21 ALB. L.J. SCI. \& TECH. 385, 417-18, 428-29 (2011) (expanding on the creation of the ACTA Committee).

40 See Yu, supra note 5, at 1024.

41 See id. at 1024-28; Port, supra note 34, at 1161-62 (explaining how the ACTA is policy laundering because it circumvented all domestic political processes and normal international treaty making processes); Kravets, supra note 1 (arguing that the ACTA is policy laundering and pointing to the secrecy that surrounded it); Higgins \& Sutton, supra note 31 (arguing that Lehman took advantage of the international forum to pass provisions that would not pass domestically).

42 See Malcolm \& Sutton, supra note 10; Malcolm, supra note 10; Canada Caves, supra note 10. For a discussion on earlier leaked draft texts, see Sean M. Flynn et al., The U.S. Proposal for an Intellectual Property Chapter in the Trans-Pacific Partnership Agreement, 28 AM. U. INT'L L. REv. 105 (2012) (explaining the conflicts with public interests in the TPP Intellectual Property chapter); Kimberlee Weatherall, Copyright in the Trans-Pacific Partnership Echoes Past Mistakes, Conversation (Oct. 24, 2014), http://theconversation.com/copyright-in-the-trans-pacific-partnership-echoes-past-mistak es-32 885 [http://perma.cc/6BWS-VJER] (detailing the public policy problems the TPP Intellectual Property chapter creates from an Australian perspective); Trans Pacific Partnership Agreement: Intellectual Property Chapter, ARTiCle 19 (Nov. 28, 2013), http:// www.article19.org/resources.php/resource/37375/en/trans-pacific-partnership-agreement :-intellectual-property-chapter [http://perma.cc/85ZB-SDK8] (commentary by Article 19, an NGO devoted to freedom of expression and freedom of information issues, summarizing the leaked Intellectual Property chapter).

43 Something to Hide, supra note 10; see also Trans-Pacific Partnership 
commenting on an early U.S. proposal, gave the blunt assessment that it was "an incredibly unbalanced proposal emanating from an extraordinarily imbalanced process." 44

Policy laundering in the copyright sphere has resulted in (or has threatened) provisions that tilt the copyright balance in rightsholders' favor, at the expense of the general public. The DMCA's anti-circumvention provisions have been used to stifle freedom of expression and academic research. ${ }^{45}$ In addition, the ambit of anticircumvention (which covers circumvention done to enable what would otherwise constitute fair use under U.S. copyright law) has given rights-holders the ability unilaterally to circumscribe fair use through DRM. ${ }^{46}$ ACTA and TPP intellectual property provisions are similarly unbalanced in favoring the interests of rightsholders-without corresponding increases in exceptions and limitations for the public good. By presenting oppressive substantive copyright provisions as a fait accompli required to comply with international obligations, policy launderers circumvent domestic channels for policy-setting and legislative debate and forestall domestic initiatives for copyright reform. ${ }^{47}$

\section{B. Policy Laundering in Other Fields}

Instances of policy laundering also occur in a variety of other fields. Mathias Koenig-Archibugi has argued that Germany and Italy have extensively used the (then) European Community ("EC") as a vehicle for laundering foreign and security policy. ${ }^{48}$ Allegations of policy laundering are also common in the field of national security; the ACLU's Policy Laundering Project, for example, was formed to monitor and influence fields of

Agreement, Electronic Frontier Found., https://www.eff.org/issues/tpp [http:// perma.cc/ WH8H-27CC] (last visited Dec. 18, 2015).

44 Flynn et al., supra note 42, at 120.

45 See Unintended Consequences: Fifteen Years Under the DMCA, ELECTRONIC FrontiER FOUND. (Mar. 2013), https://www.eff.org/pages/unintended-consequencesfifteen-years-under-dmca [http://perma.cc/W5EV-MXYN]; DocTOROW, supra note 21 (explaining how the DMCA stifles free expression).

46 See Unintended Consequences, supra note 45.

47 See Yu, supra note 5, at 1025-26.

48 Mathias Koenig-Archibugi, International Governance as New Raison D’État? The Case of the EU Common Foreign and Security Policy, 10 EUR. J. INT'L REL. 147, 174 (2004). 
surveillance, identity documents, border controls, and terrorist watch-lists. ${ }^{49}$

\section{The Theory Behind Traditional Accounts of Policy Laundering}

At first glance, policy laundering seems to have received academic attention only recently; the earliest references to the phrase date back to 2003. ${ }^{50}$ Yet discussion of the underlying phenomenon has a much lengthier history. As early as 1971, Karl Kaiser warned that the internationalization of formerly domestic issues was "inherently incompatible with the traditional framework of democratic control." ${ }^{1}$ Kaiser argued that the traditional distinction in Western democratic theory between foreign policywhich was subject only to limited democratic control-and domestic politics would become increasingly untenable with the convergence between the two areas. $^{52}$ As a result, malicious executive branches could partially escape responsibility to their respective legislatures by "pointing to the involvement of other governments and to their shared responsibility for common measures,"53 or prevent legislative or public input into multinational decision-making before presenting them with a fait accompli. ${ }^{54}$ Even if the executive intended to submit to democratic control, Kaiser added, the system of multinational interactions is too complex for executive actors to understand, never mind master. ${ }^{55}$ Although Kaiser assumed that executives might engage in policy laundering with benign intentions, ${ }^{56}$ later literature has imputed

49 See Press Release, ACLU, ACLU Announces International Project to Stop “Policy Laundering” (Apr. 13, 2005), https://www.aclu.org/news/aclu-announcesinternational-project-stop-policy-laundering [https://perma.cc/TSA4-F3E5]. The ACLU's Policy Laundering website has been shut down.

50 See Ian Hosein, The Sources of Laws: Policy Dynamics in a Digital and Terrorized World, 20 INFO. SOC’Y 187, 187 (2004) (introducing the term “policy laundering”).

51 Karl Kaiser, Transnational Relations as a Threat to the Democratic Process, 25 INT’L ORG. 706, 706 (1971).

52 Id. at 707.

53 Id. at 713.

54 Id. at 714 .

$55 \mathrm{Id}$.

56 Id. 
more self-serving motives. ${ }^{57}$ In a 1994 working paper, Andrew Moravcsik made three key arguments. ${ }^{58}$ First, international negotiations and institutions change the "domestic institutional[,] informational[,] and ideological context in which domestic policy is made."59 In particular, redefining "domestic policy" issues as "foreign policy" enabled control of which domestic actors could initiate policy, altered the constitutional and statutory environment in which policy decisions were adopted and implemented, created (or eliminated) informational asymmetries, and changed the available justifications for policies. ${ }^{60}$ Second, Moravcsik argued that such re-allocation generally favors actors who participate directly and most frequently in international negotiations and institutions - typically executive branches. ${ }^{61}$ Third, the shift in domestic power toward such actors facilitates international cooperation by encouraging the formation of "executive cartels." 62 Moravcsik then applied his framework to the (then) European Community and concluded that the "democratic deficit" it engendered was "an integral part of the EC's institutional design," in that it conferred greater domestic influence on executives. ${ }^{63}$ Moravcsik suggested that national executives "seek to create institutions that permit them to control international agendas, circumvent domestic ratification, reach decisions in secret, and exploit strong, ambiguous 'grand strategic' ideologies," as well as to insulate new policies from national interest groups or future governments of a different party. ${ }^{64}$ However, Moravcsik did not suggest that the primary motivation of national executives in entering into international institutions is to maximize their internal autonomy. ${ }^{65}$

Unlike Moravcsik, Klaus Dieter Wolf contended that autonomy

57 Andrew Moravcsik, Why the European Union Strengthens the State: Domestic Politics and International Cooperation 1-6 (Ctr. for European Studies, Working Paper No. 52, 1994).
58 Id. at 1.
59 Id. at 1.
60 See id. at 6.
61 Id. at 1.
62 Id. at $1-2$.
63 Id. at 3.
64 Id. at $58-59$.
65 Id. at $58-60$. 
maximization was indeed the primary objective of national executives. ${ }^{66}$ In a 1999 article, he referred to a "new raison d'état" as a threat to democratic governance. ${ }^{67}$ Wolf argued that state executives voluntarily entered into mutually binding arrangements to manipulate the domestic context and constrain the capacity of civil society to shape events by presenting them with a fait accompli and the simple binary choice to accept or reject it. ${ }^{68}$

Wolf's argument begins from two premises: (1) that governments have their own strategic interest in maximizing their autonomy; and (2) that increasing societal demands for participation and the growing prominence of transnational actors restrict that autonomy. ${ }^{69}$ Wolf argues that governments value the maintenance (or increase) of their autonomy over the pursuit of material preferences - in other words, that they will accept outcomes that detract from the "common good" provided that such outcomes maximize their autonomy. ${ }^{70}$ Wolf then sets out various options available to governments for safeguarding internal autonomy before describing the possibility of using voluntary intergovernmental arrangements. ${ }^{71}$ In Wolf's account, "[a]s soon as regulations have $a$ bearing on the internal political process, mutual selfcommitment has no longer merely restrictive implications."72 Through the use of non-transparent inter-governmental processes, state governments can manipulate the domestic context by tying their hands internationally. ${ }^{73}$

Koenig-Archibugi drew on writing by Kaiser, Moravcsik, and Wolf in posing the "collusive delegation thesis."74 The collusive delegation thesis consists of four points. ${ }^{75}$ First, governments value

66 See Klaus Dieter Wolf, The New Raison D'État as a Problem for Democracy in World Society, 5 EUR. J. INT’L REL. 333, 336-37 (1999).

67 Id. at 333. Wolf cites extensive prior literature on, inter alia, the search for external support by governments in support of internal autonomy. See id.

68 Id. at 335.

69 See id. at 336-40.

70 See id. at 340.

71 See id. at 340-42.

72 Id. at 341 (emphasis added).

73 Id. at 341-43. Wolf uses the entry into IMF commitments, as well as the Maastricht Treaty, as examples. Id.

74 Koenig-Archibugi, supra note 48, at 150.

75 Id. at 154. 
their autonomy in the domestic and international spheres. ${ }^{76}$ Second, "participation in intergovernmental negotiations and institutions tends to increase governments' domestic autonomy . . .."77 Third, governments, when considering whether to engage in international institutions, consider the effects of such engagement on their domestic autonomy as well as the direct benefits of such engagement. ${ }^{78}$ Fourth, when faced with a trade-off between internal and external autonomy, governments will choose the solution that improves their overall autonomy. ${ }^{79}$

The analytical framework of collusive delegation sheds light on the motivations behind traditional accounts of policy laundering. ${ }^{80}$ Although the language of policy laundering suggests that the objective is to advance a particular substantive policy despite domestic political opposition, the literature on collusive delegation suggests that this is not, in fact, the sole (or even primary) objective. ${ }^{81}$ Although the executive may need to achieve a certain substantive outcome to legitimize its continued existence, ${ }^{82}$ a primary objective - if not the primary objective_-of the executiveas-strategic-actor in participating in international fora is to maximize its net autonomy (i.e., the sum of its internal and external autonomy). ${ }^{83}$

\section{Intra-Executive Policy Laundering}

\section{A. The Theory Behind Intra-Executive Policy Laundering}

The existing literature on policy laundering and collusive delegation assumes that the executive within a particular State is a monolithic entity. ${ }^{84}$ For instance, Wolf offers "Machiavellian advice to a government seeking to maximize its autonomy in contemporary multi-level governance." ${ }^{85}$ The existing literature

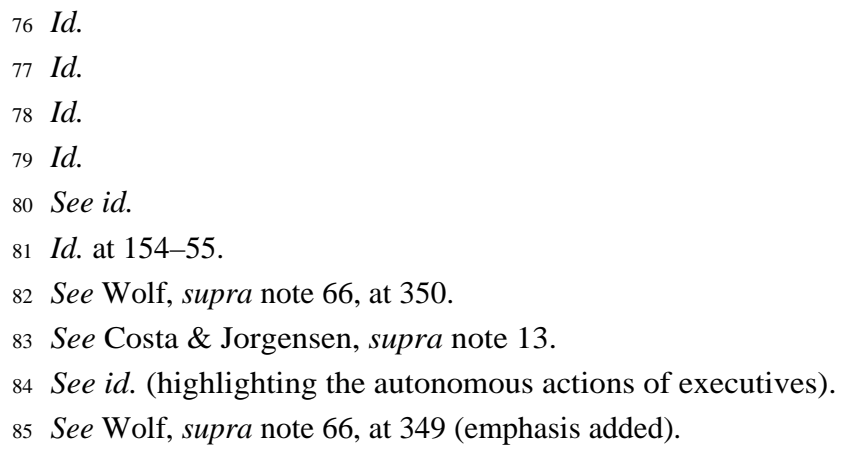


also assumes that the targets of policy laundering are "legislatures, interest groups and other societal actors." ${ }^{\text {" }}$ Although Kaiser suggested that the rise of transnational relations would increase the role of "technical" ministries (such as financial regulators) in foreign policy at the expense of foreign ministries, he did not explore the implications of that development. ${ }^{87}$ There has also been previous discussion of competition between executive agencies involving international coordination, but without explicitly linking the phenomenon to the broader literature on policy laundering. ${ }^{88}$

This article links the academic discussion of competition between executive agencies involving international coordination to the literature on policy laundering. Unlike traditional accounts of policy laundering, which assume the existence of monolithic governments with their own interests and preferences, intraexecutive policy laundering assumes the existence of diverse interest groups within the executive competing for the power to set executive policy. ${ }^{89}$ It suggests that the same forces that induce the executive as a whole to engage in policy laundering-namely the desire to maximize internal autonomy vis-a-vis legislatures and civil society, and external autonomy in the international arena-also apply to individual agencies within the executive vis-a-vis other executive agencies and counterpart regulators in other States. ${ }^{90}$ Although intra-executive policy laundering may accompany or exacerbate policy laundering by the executive as a whole, the formation of the "executive position" for the purposes of the latter form of policy laundering may itself involve intra-executive policy laundering.

Theories of regulation provide support for the idea of intraexecutive policy laundering. Regardless of whether a particular theory assumes that regulators act in the public interest or in pursuit of their own self-interest, such regulators must nonetheless

86 Moravcsik, supra note 57, at 1.

87 See Kaiser, supra note 51, at 711-12.

88 See Daniel Hemel, Regulatory Consolidation and Cross-Border Coordination: Challenging the Conventional Wisdom, 28 YALE J. ON REG. 213, 223-25 (2011); Enrico Colombatto \& Jonathan R. Macey, A Public Choice Model of International Economic Cooperation and the Decline of the Nation State, 18 CARDOZO L. REv. 925, 925-28 (1996) (discussing internal coordination with regulatory bodies).

89 See Colombatto \& Macey, supra note 88, at 930-31.

90 See id. at 929-32. 
seek autonomy in order to pursue their other objectives. ${ }^{91}$ As Colombatto and Macey argue, "[a]ll else equal, regulators would prefer not to cede or to share authority with their counterparts from other countries." 92 However, faced with domestic policymaking constraints, executive entities have less to lose by entering into international agreements. ${ }^{93}$ On the contrary, such entities may have much to gain from entry into such agreements. One such benefit is the ability to cloak their desired policies in a veneer of international credibility. ${ }^{94}$ Another is to restrict the policy options available to other domestic regulators. ${ }^{95}$ Indeed, many of the premises in Koenig-Archibugi's collusive delegation thesis arguably lend themselves to intra-executive policy laundering. ${ }^{96}$ If Koenig-Archibugi's premises are reframed with reference to entities within an executive, rather than to a monolithic executive, they might be restated in the following terms:

1) Entities within the executive value their capacity to act autonomously vis-a-vis competing executive entities ("internal autonomy"), as well as vis-a-vis their counterpart executive entities in other States ("external autonomy");

2) Participation in international institutions tends to increase the internal autonomy of executive entities and increase their influence within the executive as a whole;

3) When considering whether to participate in international institutions, an executive actor will consider not only whether such international coordination will advance its particular policy preferences, but also its effects on the actor's internal autonomy; and

4) When deciding whether to participate in international institutions, an executive actor will select the option that most

\footnotetext{
91 See Hemel, supra note 88, at 227-28.

92 See Colombatto \& Macey, supra note 88, at 926 (emphasis added).

93 See Hemel, supra note 88, at 228.

94 See id. at 229-30.

95 See id. at 228-29.

96 See Mathias Koenig-Archibugi \& Michael ZÜrn, New Modes of Governance in the Global System: Exploring Publicness, Delegation and INCLUSIVENESS 12-16 (2005) (positing that the three dimensions on which entities decide governance arrangements are publicness, delegation, and inclusiveness).
} 
advances its overall autonomy (i.e., the sum of its internal and external autonomy).

The differences between traditional accounts of policy laundering and intra-executive policy laundering are summarized in the following table:

\begin{tabular}{|c|c|c|}
\hline & Traditional Accounts & Intra-Executive \\
\hline $\begin{array}{l}\text { Nature of } \\
\text { Executive }\end{array}$ & Monolithic executive & $\begin{array}{l}\text { Competing interest } \\
\text { groups within } \\
\text { executive }\end{array}$ \\
\hline $\begin{array}{l}\text { Laundering } \\
\text { Entity }\end{array}$ & Monolithic executive & Entity within executive \\
\hline $\begin{array}{c}\text { Internal } \\
\text { Autonomy } \\
\text { Goals }\end{array}$ & $\begin{array}{l}\text { Maximize autonomy } \\
\text { vis- } a \text {-vis } \\
\text { legislature and civil } \\
\text { society }\end{array}$ & $\begin{array}{l}\text { Maximize autonomy } \\
\text { vis- } a \text {-vis } \\
\text { other executive entities }\end{array}$ \\
\hline $\begin{array}{l}\text { External } \\
\text { Autonomy } \\
\text { Goals }\end{array}$ & $\begin{array}{c}\text { Maximize autonomy } \\
\text { vis- } a \text {-vis } \\
\text { other States }\end{array}$ & $\begin{array}{l}\text { Maximize autonomy } \\
\text { vis-a-vis counterpart } \\
\text { executive entities in } \\
\text { other States }\end{array}$ \\
\hline Policy Goals & $\begin{array}{l}\text { Impose policy on } \\
\text { legislature and civil } \\
\text { society }\end{array}$ & $\begin{array}{l}\text { Impose policy on other } \\
\text { executive entities }\end{array}$ \\
\hline
\end{tabular}

\section{B. A Hypothetical Example}

Hemel provides an illustration of intra-executive policy laundering (albeit without describing it as such):

Imagine three regulators (1, 2, and 3 ) choose among three policy options (A, B, and C). Regulator 1 prefers A to B and B to C. Regulator 2's preference order is B, then C, then A. Regulator 3's preference order is $\mathrm{C}$, then $\mathrm{A}$, then $\mathrm{B}$. All regulators prefer $\mathrm{A}, \mathrm{B}$, and $\mathrm{C}$ to the status quo, but no single policy option generates a 
consensus (or even a majority). The consequence is a voting "cycle": "policy proposals can just go around and around with no end." The cycle will end only if one actor delimits the menu of options.

International institutions can enable domestic actors to assert control over the policy agenda by forcing a choice between two options. For example, regulator 2 and her cross-border counterparts may sign an agreement adopting option B. This forces regulators 1 and 3 to choose between ratification and rejection of the accord (B versus the status quo). ${ }^{97}$

In the above hypothetical, Regulator 2 has engaged in intraexecutive policy laundering in order to impose her chosen policy decision on Regulators 1 and 3.

The interaction between intra-executive policy laundering and regular accounts of policy laundering can be illustrated by adding one further element to the hypothetical. Posit that, in addition to Regulators 1,2 , and 3, there exists a domestic legislature that is opposed to all of options A, B, and C; in other words, it prefers to maintain the status quo. Once Regulator 2 has laundered her chosen policy (option B) - thus compelling other executive agencies to fall into line-the executive as a whole might then engage in policy laundering (as traditionally understood) by forcing the legislature to accept option B.

\section{Intra-Executive Policy Laundering in Action}

\section{A. When Would Executive Entities Policy Launder?}

Koenig-Archibugi's four premises above (as adapted) can provide several working hypotheses regarding when executive entities will engage in intra-executive policy laundering. ${ }^{98}$ When deciding whether to participate in international coordination, an executive entity will select the option that most advances its overall autonomy. ${ }^{99}$ This suggests that an executive entity with restricted internal autonomy but expansive external autonomy will be willing to sacrifice some of its external autonomy if the sacrifice will result in a more-than-equivalent increase in internal autonomy-in other words, it will engage in intra-executive policy laundering.

97 Hemel, supra note 88, at 228-29 (internal citations omitted).

98 See KoENIG-ARChIBUgI \& ZÜRN, supra note 96.

99 See id. 
Conversely, an executive entity with expansive internal autonomy will have little incentive to engage in international coordination that will likely decrease its external autonomy.

\section{B. Example 1-the Basel Accords}

The Basel I and II Accords are notable examples of intraexecutive policy laundering. Basel I, which was signed in July 1988, imposed common capital standards on banks. ${ }^{100}$ However, it did not impose common liquidity requirements. ${ }^{101}$ Nor did it achieve its purported effect of "levelling the playing field" between American and Japanese banks. ${ }^{102}$ The background to both Basel I (and the subsequent Basel II) show how the Federal Reserve engaged in intra-executive policy laundering to increase its autonomy vis-a-vis other American financial regulators, while also advancing its own substantive policy agenda.

Multiple agencies exercise regulatory authority over commercial banks in the United States. The Federal Deposit Insurance Corporation ("FDIC"), the Treasury Department's Office of Comptroller of the Currency ("OCC"), the Office of Thrift Supervision ("OTS"), and the Federal Reserve each assume responsibility for disparate parts of the United States banking system. ${ }^{103}$ The Federal Reserve's domestic regulatory authority is comparatively weak, both in terms of the number of institutions supervised and in terms of the value of bank assets. ${ }^{104}$ However, it enjoys far stronger international connections than its domestic regulatory rivals do. Federal Reserve officials have engaged in regular meetings with other central bankers at the Bank for International Settlements' Basel headquarters since 1974; ${ }^{105}$ although the OCC and FDIC now each have one seat on the Basel Committee, the Federal Reserve continues to hold two seats on the Committee. ${ }^{106}$

100 See BASEl Comm. on Banking Supervision, InTernational Convergence of Capital Measurement and Capital Standards 3, 14 (1988), http://www.bis.org/ publ/bcbs04a.pdf [http://perma.cc/6S7X-VA5B].

101 Hemel, supra note 88, at 231-32.

102 Id.

103 See id. at 232-33.

104 See id.

105 Id. at 235-36.

106 Basel Committee Membership, BANK FOR INT’L SETTLEMENTS, http://www.bis.org/bcbs/membership.htm [http://perma.cc/A23D-T7J3] (last visited 
Although Federal banking regulators agreed on the need for some form of capital reserve regulation in the wake of the Continental Illinois National Bank collapse, ${ }^{107}$ they vociferously disagreed on the appropriate regulatory solution. ${ }^{108}$ The Federal Reserve's preferred "risk bucket" approach faced opposition not only from the FDIC, but also from the Reagan Administration. ${ }^{109}$ To break the regulatory deadlock, Federal Reserve Chairman Paul Volcker reached an agreement with his UK counterpart, Bank of England Governor Robin Leigh-Pemberton, to endorse the "risk bucket” approach. ${ }^{110}$ This agreement ultimately led to the Basel I accord-which endorsed the Federal Reserve's preferred approach. Competing domestic regulators reluctantly acquiesced. ${ }^{111}$

The Basel II accord represents another example of successful intra-executive policy laundering by the Federal Reserve. ${ }^{112}$ In 1996, then-Federal Reserve Chairman Alan Greenspan came to favor the "value at risk" ("VaR") model of risk management-a view shared by other central bankers, but not by other U.S. banking regulators. ${ }^{113}$ Basel II, released in 2001, adopted the VaR approach; attempts by the OCC and FDIC to block its implementation in the United States were ultimately unsuccessful. ${ }^{114}$ The result of Basel II was that "[w]hat had been a three-way fight among domestic regulators ... now looked like a quixotic attempt by the FDIC and the [OCC] to roll back the advance of cutting-edge riskmanagement techniques that were being implemented in other countries." 115

Neither Basel I, nor Basel II, lends itself to explanation through a traditional policy laundering analysis. ${ }^{116}$ The background to both accords reflects strong disagreements between Federal banking regulators, rather than a unified position held by the Executive; the

Nov. 3, 2015).

107 Hemel, supra note 88, at 233.

108 See id. at 233-35.

109 Id. at 234-35.

110 Id. at 236.

111 See id. at 237.

112 Id. at 240.

113 Id.

114 Id. at 240-41.

115 Id. at 241.

116 See id. at 238-41. 
internal discord was such that a House of Representatives subcommittee hearing on Basel II was subtitled "In Search of a Unified U.S. Position."117 The Federal Reserve's limited domestic control over banking regulation led it to engage in intra-executive policy laundering to strengthen its position vis- $a$-vis other domestic banking regulators. ${ }^{118}$

\section{Example 2-the European Union and Copyright Reform}

On December 5, 2013, the Internal Market and Services Directorate-General of the European Commission launched its public consultation on copyright reform within the EU. ${ }^{119}$ The thirty-six-page consultation document covered a wide range of topics, ${ }^{120}$ including the territoriality of rights clearances, ${ }^{121}$ the idea of a single European copyright title, ${ }^{122}$ and the creation of a registration system for works created within the EU. ${ }^{123}$ Notably, major consultation topics included limitations and exceptions to copyright (both generally and with reference to specific exceptions such as research, education, and access for the disabled), ${ }^{124}$ as well as enforcement and intermediary liability. ${ }^{125}$ One of the key questions canvassed was whether the fact that most of the limitations and exceptions listed in the EU copyright directives were

117 The New Basel Accord: In Search of a Unified U.S. Position: Hearing Before the Subcomm. on Fin. Insts. \& Consumer Credit of the H. Comm. on Fin. Servs., 108th Cong. 1-2, 6-8, 84 (2003), http://commdocs.house.gov/committees/bank/hba91770.000/ hba91770_0f.htm [http://perma.cc/XE6B-EQM4].

118 See Hemel, supra note 88, at 249.

119 Public Consultation on the Review of the EU Copyright Rules, EUR. Commission, http:/ec.europa.eu/internal_market/consultations/2013/copyright-rules/ index_en.htm [http://perma.cc/AXG4-CET9] (last updated July 23, 2014).

120 European Comm'n, Public Consultation on the Review of the EU COPYRIGHT RULES 1 (2013), http://ec.europa.eu/internal_market/consultations/ 2013/copyright-rules/docs/consultation-document_en.pdf [http://perma.cc/Y64Y-X6RX] [hereinafter EU CONSULTATION DOCUMENT].

121 Id. at $7-10$.

122 Id. at 36.

$123 \mathrm{Id}$. at 14 .

$124 \mathrm{Id}$. at $16-30$.

125 Id. at 34-36. These latter topics are viewed as stalking horses for a maximalist copyright agenda. See Paul Keller, Commission Announces Public Consultation on the Review of EU Copyright Rules, Communia (Dec. 11, 2013), http://www.communiaassociation.org/2013/12/11/commission-announces-public-consultation-on-the-review-of -eu-copyright-rules/ [http://perma.cc/E5KE-P6EB]. 
optional caused problems, suggesting that the Directorate-General might be open to increasing the number of mandatory limitations and exceptions. ${ }^{126}$ Yet another Directorate-General within the Commission appears to have been moving in the opposite direction. $^{127}$

Following the European Parliament's rejection of ACTA on July 4, 2012, Trade Commissioner Karel de Gucht pledged not to launder ACTA's online copyright enforcement provisions through the Transatlantic Trade and Investment Partnership (“TTIP”) agreement, then being negotiated with the United States:

ACTA, one of the nails in my coffin. I'm not going to reopen that discussion. Really, I mean, I am not a masochist. I'm not planning to do that .... If the Commission advances new basic legislation, which I think she should, we will revisit the question, but I'm not going to do this by the back door. ${ }^{128}$

Private statements by officials in the Directorate-General of Trade paint a very different picture. In a closed-door meeting with corporate lobbyists on December 5, 2013 on the intellectual property provisions of TTIP, Pedro Velasco Martins, the Commission's chief intellectual property negotiator, reportedly disclosed the existence of a corporate "Christmas list" of intellectual property provisions for TTIP that the Commission was working to implement, including upward harmonization of copyright protection. ${ }^{129}$ Velasco Martins reportedly referred to criticism by NGOs and the public as "a risk" and considered it desirable to keep the European Parliament and civil society "in the dark" about TTIP's IP provisions. ${ }^{130}$ The negotiations of TTIP have been shrouded in secrecy, with copies of the text only viewable by national and EU representatives in a secure "reading room."131

\footnotetext{
126 EU Consultation Document, supra note 120, at 16-18.

127 Id.

128 TTIP FAQ: The Negotiation Phase, 2nd Round, MARIETJE SCHAAKE, http://archive.is/JraPG [https://perma.cc/CZS8-GC7R] (last updated Oct. 4, 2013); see also EuRopean Comm'N, How Much Does the TTIP Have In COMMON With ACTA? (2013), http://trade.ec.europa.eu/doclib/docs/2013/july/tradoc_151673.pdf [http://perma. cc/LSA2-KJ5P] (posing and answering questions regarding TTIP and ACTA).

129 E-mail from Ulf Pettersson, Policy Advisor to Amelia Andersdotter MEP, to Greens/European Free Alliance (Dec. 18, 2013, 4:42 PM (GMT+1)), http://icg.greensefa.org/pipermail/hub/2013-December/000083.html [http://perma.cc/PR46-SX2X].

130 Id.

131 Zachary Davies Boren, TTIP Controversy: Secret Trade Deal Can Only Be Read
} 
As with the Basel accords, an analysis purely in terms of existing accounts of policy laundering is inadequate. One could argue that the European Commission is behaving as a monolithic executive entity, and that its public consultations and private statements are merely two sides of the same coin-a concerted attempt to hoodwink the European Parliament and the broader public. Yet intra-executive policy laundering provides a more plausible explanation.

In particular, several aspects of the Trade Directorate-General's prior conduct in similar trade negotiations point to the existence of intra-executive policy laundering. The negotiation of IP enforcement provisions in TTIP may exceed the authority conferred by the negotiation mandate given to the Commission by the European Council; the mandate allegedly prohibits the inclusion of provisions on IP-related criminal sanctions. ${ }^{132}$ Insofar as the negotiation mandate is ultra vires that mandate, the Commission would be at odds with the European Council. Such behavior would be consistent with previous conduct by the Trade DirectorateGeneral, and with bureaucratic politics in Brussels. Further, the pending EU-Singapore Free Trade Agreement features provisions that have been copied, almost word for word, from ACTA. ${ }^{133}$ The

in Secure "Reading Room" in Brussels, InDEPENDENT (Aug. 14, 2015), http://www.independent.co.uk/news/world/europe/ttip-controversy-secret-trade-deal-canonly-be-read-secure-in-reading-room-in-brussels-10456206.html [http://perma.cc/3UH6HK9X].

132 Id. The full text of the negotiating mandate has not been made public. However, paragraph 30 of the mandate allegedly states, "The Agreement shall not include provisions on criminal sanctions.” PIETER JAN KUIJPER ET AL., THE LAW OF EU EXTERNAL RELATIONS 64 (2d ed. 2015); see also Member States Endorse EU-U.S. Trade and Investment Negotiations, EUR. COMMISSION (June 14, 2013), http://trade.ec.europa.eu/doclib/press/index.cfm?id=918 [http://perma.cc/2KM4-HJVR] (discussing how mandate gives go ahead for the EU to enter into formal bilateral trade negotiations with the United States); MARIETJE SCHAAKE, supra note 128 (quoting paragraph 30 of the approved negotiating mandate).

133 Compare EU-Singapore Free Trade Agreement, EU-Sing., art. 11.44.1-2, May 22, 2015, http://trade.ec.europa.eu/doclib/press/index.cfm?id=961 [http://perma.cc/JR63GMVN] (providing authentic text as of May 2015 of pending agreement), with AntiCounterfeiting Trade Agreement art. 9.1-2, opened for signature May 1, 2011, 50 I.L.M. 243, https://ustr.gov/acta [https://perma.cc/GA35-HGGR] (providing final text of the agreement). See Glyn Moody, European Commission: ACTA Is Dead, Long Live ACTA?, TECHDiRT (Oct. 23, 2013), https://www.techdirt.com/articles/20131022/07350824965/euacta-is-dead-long-live-acta.shtml [http://perma.cc/TZ8R-DJTA] (showing that the language was pulled directly from the ACTA). 
Trade Directorate-General would likely have played a major role in the negotiation of both agreements; it would therefore not be surprising that the Directorate-General would seek to revive the failed substantive agenda embodied in ACTA through the inclusion of its provisions in other instruments. In addition, there is a documented history of rivalry between Directorates-General and failures to coordinate within the Commission. ${ }^{134}$ Against such a background, an account of policy laundering that considers intraexecutive rivalry is more convincing than one that presupposes a Commission that speaks with one voice.

\section{A Counter-Example: When Will an Executive Actor Act Alone?}

If the hypotheses in subpart A are correct, an executive entity with extensive internal autonomy would have little incentive to participate in international institutions. Doing so would merely restrict the entity's external autonomy, with minor gains in internal autonomy at best (and perhaps even a reduction in internal autonomy).

The USTR's continued use of “Special 301" reports appears to bear out this hypothesis. The Special 301 regime, created by Congress in 1988 as a response to perceived inadequacies in international intellectual property enforcement, requires USTR to identify countries that do not adequately protect U.S. intellectual property interests. ${ }^{135}$ The Agreement on Trade Related Aspects of Intellectual Property Rights (“TRIPS”) subsequently incorporated minimum standards of intellectual property protection-as well as provisions on enforcement and dispute settlement-into the World Trade Organization framework (“WTO”). ${ }^{136}$ Yet, despite TRIPS' entry into force-and despite a WTO dispute regarding the use of unilateral determinations by the United States ${ }^{137}$ — the USTR has

134 Roger Levy, Implementing European Union Public Policy 15 (2000); see also Former EU Mandarin Spills the Beans on Commission Intrigue, DeUTSCHE WELLE (Sept. 21, 2007), http://www.dw.de/former-eu-mandarin-spills-the-beans-on-commissionintrigue/a-2790009-1 [http://perma.cc/TK9Y-JXBV] (discussing the real power in the Commission).

135 See 19 U.S.C. § 2411 (2015); see also Robert J. Pechman, Seeking Multilateral Protection for Intellectual Property: The United States “TRIPs” over Special 301, 7 MiNN. J. Global Trade 179, 195-97 (1998) (discussing the development of Special 301).

136 Pechman, supra note 135, at 184-89.

137 For a summary of the relevant WTO dispute, see United States - Sections 301- 
continued to make extensive use of the Special 301 framework. ${ }^{138}$ One plausible explanation is the preservation of internal autonomy. Under the Special 301 framework, the USTR enjoys extensive net autonomy in determining whether the United States' trading partners adequately protected American intellectual property rights. WTO dispute proceedings, on the other hand, would involve a reduction in the USTR's external autonomy with no corresponding gain in internal autonomy. As a result, the USTR had little incentive to abandon the unilateral Special 301 mechanism to advance its substantive agenda.

\section{Descriptive and Normative Conclusions}

\section{A. Descriptive Conclusions}

The above examples (and counter-example) of intra-executive policy laundering appear to confirm that the same considerations that result in "collusive delegation" or policy laundering by executives as a whole also apply to individual actors within the executive. To restate the hypotheses stated in Part III.A above:

1) An executive entity with restricted internal autonomy but expansive external autonomy will be willing to sacrifice some of its external autonomy, if this will result in a more-than-equivalent increase in internal autonomy; and

2) Conversely, an executive entity with expansive internal autonomy will have little incentive to engage in international coordination that will likely decrease its external autonomy.

As an increasing number of policy areas become the subject of international coordination, the collusive delegation thesis suggests that a number of consequences will follow. First, intra-executive turf battles will increasingly be waged on multiple fronts. Not only will executive entities compete amongst themselves in the domestic arena, they will also engage in a "race to coordinate" with counterpart agencies in other States. ${ }^{139}$ Second, increased transnational coordination will tend to favor executive agencies

310 of the Trade Act, WORLD TRADE ORG., http://www.wto.org/english/tratop_e/ dispu_e/cases_e/ds152_e.htm [http://perma.cc/CTQ2-X75D] (last visited Sept. 10, 2015).

138 For the latest Special 301 Report, see OfFICE OF THE U.S. TradE REPRESENTATIVE, EXEC. OfFice OF THE PRESIDENT, 2014 SPECIAL 301 REPORT (2014), https://ustr.gov/ sites/default/files/USTR\%202014\%20Special\%20301\%20Report\%20to\%20Congress\%2 0FINAL.pdf [https://perma.cc/PDT5-697A].

139 See Hemel, supra note 88, at 227. 
with more extensive international connections. Third, the resulting intra-executive policy laundering may tend to exacerbate policy laundering by the executive as a whole. Intra-executive policy laundering involves one executive entity entering into agreements with its foreign counterparts; once the policy agenda of the executive as a whole has been set, the international agreement used to set that agenda lends itself to policy laundering as against the legislature and civil society.

\section{B. Normative Conclusions}

The same criticisms that attend traditional accounts of policy laundering or collusive delegation also apply to intra-executive policy laundering. In particular, by giving an executive actor control over the power to initiate policy and creating informational asymmetries, ${ }^{140}$ intra-executive policy laundering is likely to have adverse effects on public participation and transparent decisionmaking. The involvement of a plethora of executive actors, all of whom seek to seize policy initiative and keep other executive actors in the dark, is likely to exacerbate the difficulties faced by legislatures and civil society in taking (or re-taking) policy initiative or accessing information. Instead of facing one "opponent," as is the case in traditional accounts of policy laundering, such actors now face several. The inability to identify one particular focal point for opposition will also make it more difficult for civil society to muster opposition to a particular policy allegedly being laundered. These developments suggest that intra-executive policy laundering makes it easier for one executive agency - in particular, one with limited domestic autonomy or legitimacy-to impose its view of the common good on other executive bodies, as well as on the public.

Yet intra-executive policy laundering may have some redeeming virtues. As with traditional accounts of policy laundering, intra-executive policy laundering may help achieve "beneficial" substantive outcomes, as well as insulate certain policy decisions from domestic political forces. ${ }^{141}$ However, intraexecutive policy laundering may have its own distinct benefits. The creation of an additional layer of competition between executive agencies may help to break the deadlock between multiple agencies; in the hypothetical example in Part II.B above, the adoption of any

140 See Moravcsik, supra note 57, at 7.

141 See id. at 60. 
solution would, from a regulatory perspective, be preferable to maintaining the status quo. From the perspective of transnational cooperation and coordination, intra-executive policy laundering will tend to shift the power to set domestic policy agendas in favor of executive entities that are already more inclined to engage in such cooperation or coordination.

Nonetheless, troubling questions remain regarding the added layers of secrecy and lack of accountability. Wolf's suggestions regarding a deliberative model of democracy as a means of arriving at a conception of the common good-initially proposed as a counter to the "new raison d'état" problem-may provide a possible solution. ${ }^{142}$ However, a detailed exploration of Wolf's proposal-and its adaptation to the more complex landscape of intra-executive policy laundering -is beyond the scope of this paper.

\section{Beyond the Language of "Laundering"}

Ultimately, however, the most useful contribution that the literature on collusive delegation can make to the discussion of policy laundering-both traditional accounts and intra-executive policy laundering - is to provide a more nuanced vocabulary. The language of "policy laundering," with its reference to money laundering and its emphasis on advancing a particular substantive policy agenda, obscures the underlying objective of institutional autonomy and presupposes a particular normative conclusion. Although the term "policy laundering" has been singularly effective in bringing a phenomenon long discussed in academic literature to the public consciousness, further exploration of the topic may demand that we abandon the term for other, more useful terminology.

142 See Wolf, supra note 66, at 350-53 (describing provision of public goods and the solution of problems in ways geared to the common good). 